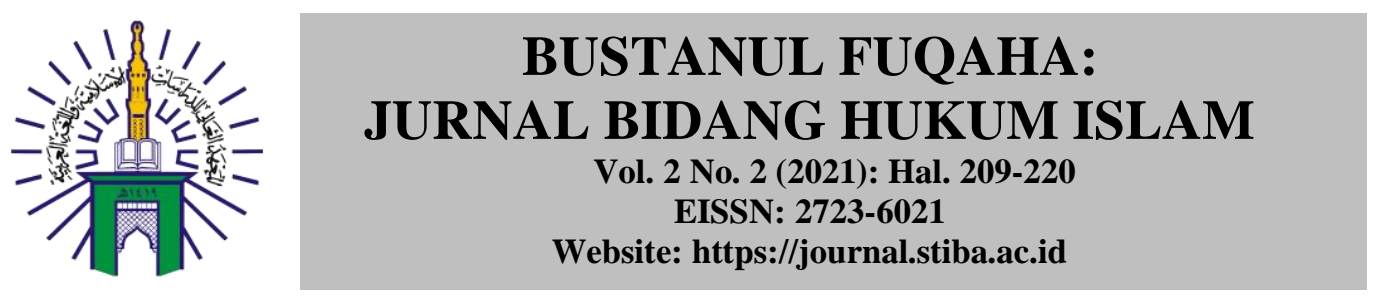

\title{
JUAL BELI DUA HARGA DALAM SATU TRANSAKSI JUAL BELI (STUDI KOMPARATIF ANTARA MAZHAB MALIKI DAN MAZHAB SYAFI'I)
}

\section{BUYING AND SELLING TWO PRICES IN ONE TRADE TRANSACTION (COMPARATIVE STUDY BETWEEN MALIKI AND SHAFI'I SECT)}

\author{
Ronny Mahmuddin \\ Sekolah Tinggi Islam dan Bahasa Arab (STIBA) Makassar \\ Email: ronny.mahmuddin@stiba.ac.id
}

\section{Zulfiah Sam}

Sekolah Tinggi Islam dan Bahasa Arab (STIBA) Makassar

Email: zufiahsam@stiba.ac.id

\section{Akhmad Hanafi Dain Yunta}

Sekolah Tinggi Islam dan Bahasa Arab (STIBA) Makassar

Email: ahmadhanafi@stiba.ac.id

\section{Mariyani Syam}

Sekolah Tinggi Islam dan Bahasa Arab (STIBA) Makassar

Email: mariani.syam@gmail.com

\begin{tabular}{ll}
\hline Keywords : & \multicolumn{1}{c}{ ABSTRACT } \\
\cline { 2 - 2 } $\begin{array}{l}\text { Maliki, Shafi'I, two prices, } \\
\text { transaction, }\end{array}$ & $\begin{array}{l}\text { This study aimed to find out and understand how to buy and sell two } \\
\text { prices in one sale and purchase transaction (Bai'atani fi bai'ah) } \\
\text { according to the perspective of the Maliki Sect and the Shafi'i Sect. } \\
\text { The study was a qualitative descriptive research (non-statistical), } \\
\text { which focuses on the study of manuscripts and texts, using a normative } \\
\text { and philosophical approach. The results of the study found several } \\
\text { things. First, according to the Maliki Sect, buying and selling two } \\
\text { prices in one trade transaction (Bai'atani fi bai'ah) is permissible } \\
\text { provided that there is certainty of an agreement to be used to pay } \\
\text { before parting. While the Shafi'i sect considers that buying and selling } \\
\text { is absolutely haram, this is due to the vagueness of the contract chosen } \\
\text { by both parties. Second, the view of the Maliki Sect is skewed stronger } \\
\text { than the view of the Shafi'i Sect, because Imam Malik considers this } \\
\text { trade should not be unless there is clarity of agreement agreed before } \\
\text { separation. The determination between the two agreements makes this } \\
\text { trade permissible according to Imam Malik. As for the opinion of } \\
\text { Imam Shafi'i is more careful, because such a trade is very vulnerable } \\
\text { to injustice, usury practice and other damage, so at one time this } \\
\text { opinion can also be used. }\end{array}$ \\
\hline $\begin{array}{l}\text { Kata kunci : } \\
\text { Maliki, Syafi'I, dua harga, } \\
\text { transaksi }\end{array}$ \\
$\begin{array}{l}\text { Penelitian ini bertujuan untuk mengetahui dan memahami bagaimana } \\
\text { jual beli dua harga dalam satu transaksi jual beli (bai'atani fi bai'ah) } \\
\text { menurut perspektif Mazhab Maliki dan Mazhab Syafi'i. Penelitian ini } \\
\text { merupakan jenis penelitian deskriptif kualitatif (non-statistik), yang } \\
\text { terfokus pada studi naskah dan teks, dengan menggunakan metode }\end{array}$ \\
\hline
\end{tabular}






Diterima: 4 Agustus 2021; Direvisi: 12 Agustus 2021; Disetujui: 12 Agustus 2021; Tersedia online: 20 Agustus 2021

How to cite: Ronny Mahmuddin, Zulfiah Sam, Akhmad Hanafi Dain Yunta, \& Mariyani Syam. "Jual Beli Dua Harga dalam Satu Transaksi Jual Beli (Studi Komparatif Antara Mazhab Maliki dan Mazhab Syafi'i)", BUSTANUL FUQAHA: Jurnal Bidang Hukum Islam 2, No. 2 (2021): 209-225. doi: 10.36701/bustanul.v2i2.360.

\section{PENDAHULUAN}

Dewasa ini, era globalisasi memberikan stimulasi pada perkembangan perekonomian. Di balik berbagai peluang yang besar yang ditawarkan, era globalisasi juga mengundang persoalan dan tantangan, terkhusus bagi kaum muslimin yang meyakini dan mengimani bahwa segala urusan kehidupannya mempunyai hukum dan aturan-aturan tertentu. Ahmad Azhar mengatakan bahwa dalam hukum Islam sudah ada aturan-aturan tertentu mengenai hubungan hak dan kewajiban manusia dalam kehidupan bermasyarakat. Aturan inilah yang disebut dengan hukum muamalat. ${ }^{1}$ Allah subhānahu wa ta' âla telah menjadikan manusia berhajat antara yang satu dengan yang lain. Hal ini mengandung sebuah isyarat agar mereka saling tolong-menolong, tukar-menukar keperluan dalam segala urusan kepentingan hidup. Beberapa caranya antara lain melalui proses jual beli, sewa menyewa, gadai, koperasi dan lain-lain.

Jual beli adalah salah satu kegiatan dalam bidang muamalat. Jual beli merupakan suatu perjanjian tukar-menukar benda atau barang yang mempunyai nilai secara sukarela di antara kedua belah pihak, yang satu menerima benda-benda dan pihak lain menerimanya sesuai dengan perjanjian atau ketentuan yang telah dibenarkan syara' dan disepakati. ${ }^{2}$ Dengan kata lain, jual beli harus memenuhi persyaratan-persyaratan, rukun-rukun, dan hal-hal lain yang ada kaitannya dengan jual beli, sehingga bila syaratsyarat dan rukunnya tidak terpenuhi berarti tidak sesuai dengan kehendak syara'. Kegiatan jual beli merupakan suatu yang telah dianjurkan untuk dilakukan oleh manusia dalam sarana pemenuhan kebutuhan hidup. Oleh karena itu, jual beli mempunyai

\footnotetext{
${ }^{1}$ Ahmad Azhar Basyir, Asas-Asas Hukum Muamalah (Yogyakarta: UII Press, 2009).

${ }^{2}$ Hendi Suhendi, Fiqh Muamalah (Jakarta: Radjagrafindo Persada, 2002).
} 




\section{BUSTANUL FUQAHA: \\ JURNAL BIDANG HUKUM ISLAM \\ Vol. 2 No. 2 (2021): Hal. 209-220 \\ EISSN: 2723-6021 \\ Website: https://journal.stiba.ac.id}

landasan yang sangat kuat di dalam Al-Qur'an dan hadis. Di antaranya firman Allah dalam Q.S. al-Baqarah/2: 275,

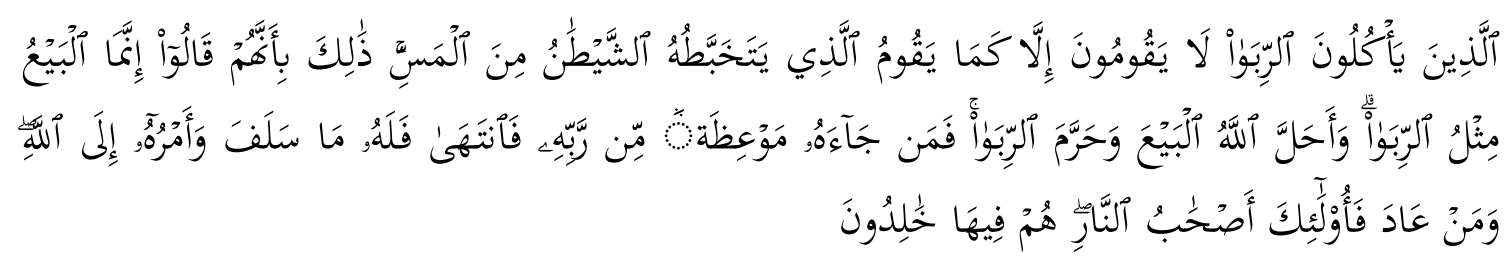

Terjemahnya:

Orang-orang yang makan (mengambil) riba tidak dapat berdiri melainkan seperti berdirinya orang yang kemasukan syaitan lantaran (tekanan) penyakit gila. Keadaan mereka yang demikian itu adalah disebabkan mereka berkata (berpendapat), sesungguhnya jual beli itu sama dengan riba, Padahal Allah telah menghalalkan jual beli dan mengharamkan riba. orang-orang yang telah sampai kepadanya larangan dari Tuhannya, lalu terus berhenti (dari mengambil riba), maka baginya apa yang telah diambilnya dahulu (sebelum datang larangan); dan urusannya (terserah) kepada Allah. Orang yang kembali (mengambil riba), maka orang itu adalah penghuni-penghuni neraka; mereka kekal di dalamnya. ${ }^{3}$

Pembayarannya pada praktek transaksi jual beli, dapat dilakukan dengan dua opsi yaitu tunai dan kredit. Namun pada prakteknya, banyak pelaku usaha menjual barangnya dengan harga yang berbeda pada transaksi tunai dan kredit. Jual beli inilah yang dimaksudkan oleh penulis dengan jual beli dua harga dalam satu transaksi jual beli (bai'atāni fì bai'ah), yaitu sebuah transaksi akad yang melingkupi jual beli tunai dan kredit secara bersamaan dengan harga yang berbeda, secara tunai dengan harga normal atau secara kredit dengan harga yang lebih tinggi.

Dalam syari'at Islam, jual beli dengan cara demikian terkait dengan konsep bai'atāni fi bai'ah, termuat dalam hadis,

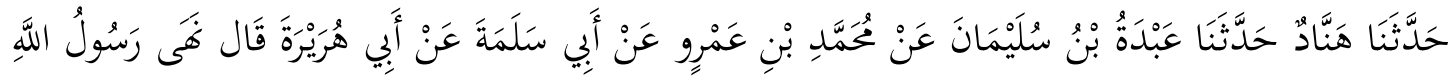

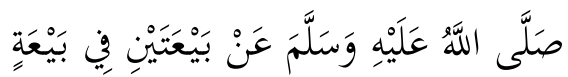

Artinya:

Hannad telah menceritakan kepada kami, dia berkata, "Abdah bin Sulaiman telah menceritakan kepada kami, dari Muhammad bin Amri, dari Abi Salamah, dari Abu Hurairah, dia berkata, 'Bahwasanya Rasulullah shallallāhu 'alaihi wasallam melarang dua akad dalam satu transaksi jual beli'.,4

Secara lahir, hadis tersebut melarang praktek dua akad jual beli yang dikemas dalam satu akad transaksi. Namun demikian, hadis di atas tampaknya belum mengemas secara utuh praktek jual beli dua harga dalam satu transaksi yang terjadi pada masyarakat dewasa ini. Bentuk dan hukum jual beli dua harga dalam satu transaksi jual beli (bai'atāni fi bai'ah) hanya dapat diperoleh penjelasannya melalui penalaran para

\footnotetext{
${ }^{3}$ Departemen Agama RI, Al Qur'an Dan Terjemahnya (Bandung: Cordoba, 2018).

${ }^{4}$ Abu Abdillah Ahmad bin Muhammad Hanbal al Syaibani, Al Musnad (Kairo: Dar al-Hadis, n.d.).
} 
ulama terhadap hadis tersebut sesuai dengan versi mereka masing-masing. Itu pula sebabnya sehingga jual beli dua harga dalam satu transaksi jual beli (bai'atāni fì bai'ah) berada dalam koridor khilafiyah.

Oleh karena itu, penelitian ini dimaksudkan untuk melihat perbedaan pendapat ulama mengenai jual beli dua harga ini. Penelitian ini mengangkat rumusan masalah: bagaimana hukum dan perbandingan pandangan mazhab Maliki dan mazhab Syafi'i tentang hukum jual beli dua harga dalam satu transaksi jual beli (bai'atāni fi bai'ah). Untuk menjawab permasalahan tersebut, penelitian ini dilakukan dengan tujuan untuk mengetahui dan memahami bagaimana jual beli dua harga dalam satu transaksi jual beli (bai'atani fi bai'ah) menurut perspektif Mazhab Maliki dan Mazhab Syafi'i. Jenis penelitian ini adalah penelitian kepustakaan (library research) yakni suatu penelitian yang bertujuan untuk mengumpulkan data dan informasi dengan bantuan materialmaterial yang terdapat di ruang perpustakaan. ${ }^{5}$ Dengan pendekatan normatif, adalah sebuah pendekatan untuk mengetahui sebuah nilai-nilai kebenaran yang menjadi objek penelitian. ${ }^{6}$ Metode pengelolaan dan analisis data yang digunakan adalah metode deduktif dan metode komparatif. Metode deduktif yaitu suatu metode analisis data yang bertolak dari pengetahuan yang bersifat umum, kemudian ditarik kesimpulan yang bersifat khusus. ${ }^{7}$ Sedangkan metode komparatif, yaitu suatu analisa dengan cara membandingkan data- data dari hasil penelitian. ${ }^{8}$

Penelitian ini bukan penelitian pertama. Sebelumnya, penelitian skripsi dengan judul "Hukum Jual Beli dengan Opsi Dua Harga Tunai dan Kredit (Studi Istinbath Hukum Mazhab Syafi'i)" oleh Fajar Khoirul Imam dari Universitas Islam Negeri Sunan Kalijaga Yogyakarta 2016. Dalam skripsi tersebut yang menjadi masalah pokok adalah hukum jual beli dua harga (tunai dan kredit) menurut pandangan mazhab Syafi'i saja. Sedangkan penelitian ini membahas hukum jual beli dua harga (tunai dan kredit) menurut pandangan mazhab Maliki dan mazhab Syafi'i.

\section{PEMBAHASAN}

\section{Konsep Jual Beli dalam Islam}

Jual beli dalam istilah fikih disebut dengan al-ba'i yang berarti menjual, mengganti dan menukar sesuatu dengan sesuatu yang lain. Lafadz al-ba' $i$ dalam bahasa Arab terkadang digunakan untuk pengertian kebalikannya, yakni kata al-syira' (beli). Dengan demikian, kata $a l-b a{ }^{\prime} i$ berarti jual, tetapi sekaligus juga berarti beli. ${ }^{9}$ Menurut bahasa, jual beli adalah "menukarkan sesuatu dengan sesuatu" atau "mengganti sesuatu dengan sesuatu". ${ }^{10}$ Secara terminologi, para fukaha menyampaikan definisi yang berbeda-beda antara lain sebagai berikut.

UGM, 1981).

\footnotetext{
${ }^{5}$ Aji Damanuri, Metodologi Penelitian Mu'amalah (Ponorogo: STAIN Po PRESS, 2010).

${ }^{6}$ Abuddin Nata, Metode Studi Islam (Jakarta: Raja Grafindo Persada, 2017).

${ }^{7}$ Sugiyono, Penelitian Bisnis (Bandung: Alfabeta, 2007).

${ }^{8}$ Sutrisno Hadi, Metode Research, 1st ed. (Yogyakarta: Yayasan Penerbit Fakultas Psikologi

${ }^{9}$ Ghufron A Mas'adi, Fiqh Muamalah Kontekstual (Jakarta: Radjagrafindo Persada, 2002).

${ }^{10}$ Abd Al Rahman al Jaziri, Kitab Al-Fiqh 'ala Al-Madzhab Al-Arba'ah, 3rd ed. (Bairut: Dar al-
} Fikr, 1972). 
Menurut Syekh Zainuddin Ibn Abd Aziz al-Malibary, jual beli adalah: ${ }^{11}$

Artinya:

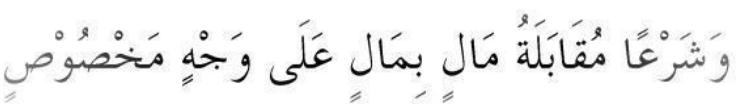

Jual beli menurut syara' ialah menukarkan harta dengan harta pada wajah tertentu.

Menurut Syekh Muhammad ibn Qasim al-Ghazzi: ${ }^{12}$

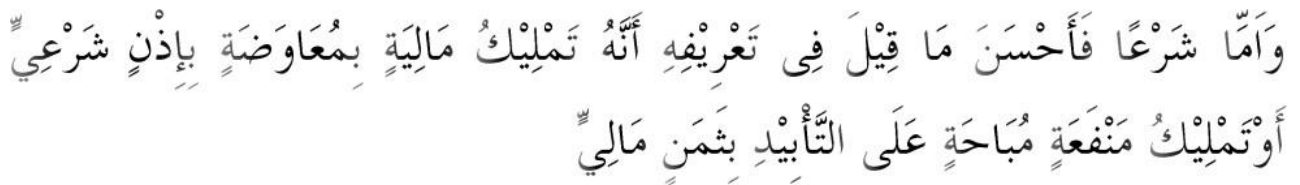

Artinya:

Menurut syara', pengertian jual beli yang paling tepat ialah memiliki sesuatu harta (uang) dengan mengganti sesuatu atas dasar izin syara', sekedar memiliki manfaatnya saja yang diperbolehkan syara' untuk selamanya yang demikian itu harus dengan melalui pembayaran yang berupa uang.

Sedangkan Imam Taqi al-Din mendefinisikan jual beli adalah saling tukar menukar harta, saling menerima, dapat dikelola (tasharruf) dengan ijab dan qabul, dengan cara yang dilegalkan syara'. ${ }^{13}$ Beberapa definisi di atas dapat dipahami bahwa inti jual beli ialah suatu perjanjian tukar-menukar benda atau barang yang mempunyai nilai secara sukarela di antara kedua belah pihak, yang satu menerima benda-benda dan pihak lain sesuai dengan perjanjian atau ketentuan yang telah dibenarkan syara' dan disepakati.

Sesuai dengan ketetapan hukum ialah memenuhi persyaratan-persyaratan, rukun-rukun dan hal-hal lainnya yang ada kaitannya dengan jual beli, maka bila syaratsyarat dan rukunnya tidak terpenuhi berarti tidak sesuai dengan kehendak syara'. Benda dapat mencakup pada pengertian barang dan uang, sedangkan sifat benda tersebut harus dapat dinilai, yakni benda-benda yang berharga dan dapat dibenarkan penggunaannya menurut syara', benda itu adakalanya bergerak (dapat dipindahkan) dan adakalanya tetap (tidak dapat dipindahkan), yang dapat dibagi-bagi dan tidak dapat dibagi-bagi, harta yang ada perumpamaannya (mitsli) dan tidak ada yang menyerupainya (qimi) dan yang lain-lainnya, penggunaan harta tersebut dibolehkan sepanjang tidak dilarang syara'. ${ }^{14}$

Dalil-dalil yang menjadi dasar disyariatkan jual beli dapat dilihat dalam beberapa ayat Al-Qur'an, hadis Nabi dan ijmak ulama (konsensus ulama), antara lain:

1. Al-Qur'an

Dasar hukum jual beli adalah surah al-Baqarah ayat 275 seperti yang telah

\footnotetext{
${ }^{11}$ Zainuddin Ibnu Abd Azis al Malibary, Fath Al-Mu'in (Semarang: Toha Putera, n.d.).

${ }^{12}$ Muhammad ibn Qasim al Ghazzi, Fath Al-Qarib (Indonesia: Dar al-Ihya al-Kitab, n.d.).

13 Taqi Al Din Abu Bakar ibn Muhammad Al-Hussaini, Kifayah Al Akhyar, 1st ed. (Surabaya: Al Haromain, 2005).

${ }^{14}$ Suhendi, Fiqh Muamalah.
} 


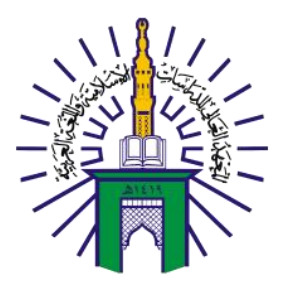

\section{BUSTANUL FUQAHA: \\ JURNAL BIDANG HUKUM ISLAM \\ Vol. 2 No. 2 (2021): Hal. 209-220 \\ EISSN: 2723-6021 \\ Website: https://journal.stiba.ac.id}

disebutkan sebelumnya. Selain itu, juga menjadi dasar jual beli adalah pada surah alNisa ayat 29 ,



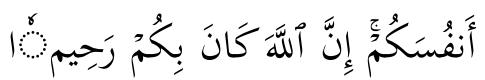

Terjemahnya:

Hai orang-orang yang beriman, janganlah kamu saling memakan harta sesamamu dengan jalan yang batil, kecuali dengan jalan perniagaan yang berlaku dengan suka sama-suka di antara kamu. Dan janganlah kamu membunuh dirimu; sesungguhnya Allah adalah Maha Penyayang kepadamu.

Dalam ayat tersebut, Allah menyeru kepada orang-orang yang beriman agar mereka tidak makan harta sesama dengan jalan yang tidak diridai oleh syara' (bathil), kecuali dengan jual beli yang di dalamnya terkandung unsur saling merelakan. Dari ayat tersebut bisa dipahami bahwa disamping jual beli itu harus memenuhi rukun dan syaratnya -yang akan penulis paparkan pada sub bab berikutnya- juga ada anjuran syarat lain yang tidak tampak ( $b a t h i n$ ), yaitu kerelaan yang tersimpan dalam hati penjual dan pembeli. Oleh karenanya, dalam melakukan transaksi membutuhkan adanya ijab dan qabul agar kerelaan yang mulanya tersimpan akan menjadi jelas.

2. Hadis



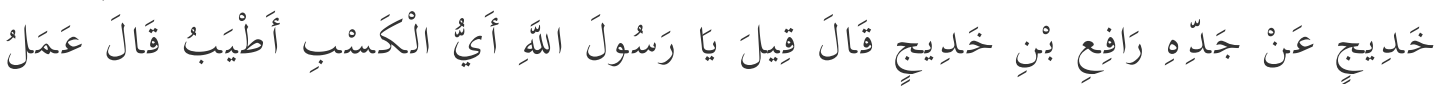

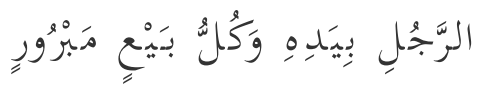

Artinya:

Telah berkata kepada kami Yazid, telah berkata kepada kami al-Mas'udi, dari Wa'il Abi Bakr, dari Abayahbin Rifa'ah bin Rafi' bin Khadij, dari Rafi' bin Khadij, dia berkata, 'Dikatakan, 'Ya, Rasulullah, pekerjaan apa yang paling bagus?' Rasulullah menjawab, 'Pekerjaan laki-laki yang mengandalkan tangannya sendiri dan semua jual beli yang baik'."15

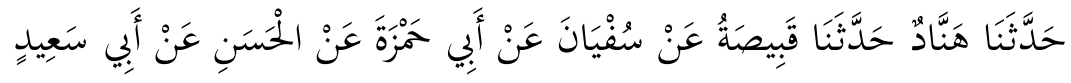

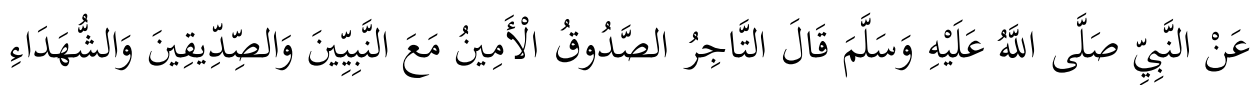

Artinya:

Menceritakan kepada kami Hannad, menceritakan kepada kami Kabisah, dari

Sufyan, dari Abu Hamzah dari Hasan, dari Abu Sa'id, dari Nabi shallallahu

15 Abu Abdillah Ahmad bin Muhammad Hanbal al Syaibani, Musnad Al-Imam Ahmad Bin Hanbal, 28th ed. (Muassasah ar-Risalah, 2001). 
'alaihi wasallam bersabda, "Pedagang yang jujur dan terpercaya sejajar (tempatnya di surga) dengan para Nabi, siddiqin dan syuhada."

Dalam hadits di atas, Nabi saw. menggambarkan kedudukan para pedagang yang jujur dan dapat dipercaya di surga bersama-sama dengan para Nabi, orang-orang yang jujur dan para syahid. Betapa tinggi derajat para pedagang jika mereka mau berusaha menerapkan sifat-sifat tersebut

\section{Ijmak}

Ulama telah sepakat bahwa jual beli diperbolehkan dengan alasan bahwa manusia tidak akan mampu mencukupi kebutuhan dirinya, tanpa bantuan orang lain. Namun demikian, bantuan atau barang milik orang lain yang dibutuhkannya itu harus diganti dengan barang lainnya yang sesuai. ${ }^{17}$

\section{Rukun dan Syarat Jual Beli}

Terkait rukun jual beli, mazhab Hanafi menyebutkan bahwa rukun jual beli hanya ijab dan kabul saja. Yang menjadi rukun jual beli hanyalah kerelaan antara kedua belah pihak untuk berjual beli. Namun demikia, mengingat bahwa unsur kerelaan berhubungan dengan hati yang sering tidak kelihatan, maka diperlukan indikator (qarinah) yang menunjukkan kerelaan tersebut dari kedua belah pihak. Hal ini dapat dilihat dalam bentuk perkataan (ijab dan qabul) atau dalam bentuk perbuatan, yaitu saling memberi (penyerahan barang dan penerimaan ganti barang tersebut). ${ }^{18}$

Menurut Imam al-Ghazali dalam kitab Ihya' Ulum al-Din, rukun jual beli itu ada tiga, yaitu: (1) aqid (penjual dan pembeli); (2) siqhad (lafal ijab dan kabul); dan (3) ma'qud (benda yang dijadikan obyek jual beli). ${ }^{19}$

\section{Peraturan dalam Jual Beli}

Peraturan atau hukum jual beli dalam Islam ditetapkan sebagai berikut:

a. Dibenarkan jual beli yang tidak berbentuk riba.

b. Dalam jual beli perlu ada ijab-qabul (tanda terima) yang diucapkan dengan lisan/perkataan dan boleh dengan hati masing-masing.

c. Dilarang memperjual belikan darah, bangkai, hasil pencurian, harta waqaf, milik umum, minuman keras, babi, barang najis, barang yang tidak ada harganya dan barang yang tidak ada pemiliknya.

d. Akad jual beli harus dilaksanakan dalam satu majelis, dapat diterima (taslim) dan dapat dipegang (qabadh).

e. Dalam jual beli dibenarkan adanya hak meneruskan atau membatalkan pembelian suatu barang (khiyar) jika misalnya terdapat cacat (aib),

f. Dalam jual beli tersebut harus dilaksanakan oleh orang yang berakal sedangkan pada

\footnotetext{
${ }^{16}$ Muhammad Isa bin Saurah bin Musa bin adh-Dhohhak at-Tarmidzi, Sunan At-Tarmidzi, Juz 3 (Mesir: Syarikah Maktabah wa Matba'ah Mustofa al-Babi al-Halbi, 1975).

${ }^{17}$ Rachmat Syafe'i, Fiqh Muamalah (Bandung: Pustaka Setia, 2001).

${ }^{18}$ M Ali Hasan, Berbagai Macam Transaksi Dalam Islam (Fiqh Muamalat), 1st ed. (Jakarta: Raja Grafindo Persada, 2003).

${ }^{19}$ Al Ghazali, Ihya 'Ulum Al Din (Jakarta: Faizan, n.d.).
} 


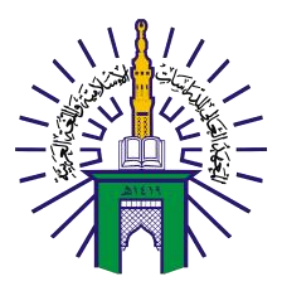

\section{BUSTANUL FUQAHA: \\ JURNAL BIDANG HUKUM ISLAM \\ Vol. 2 No. 2 (2021): Hal. 209-220 \\ EISSN: 2723-6021 \\ Website: https://journal.stiba.ac.id}

anak kecil dibenarkan pada benda-benda yang tidak bernilai tinggi, kecuali jika mereka telah dewasa.

g. Jika barang tersebut ditimbang atau diukur maka timbangan atau ukuranya tertentu dan diketahui.

h. Larangan menawar tawaran orang lain atau menjual sesuatu yang sudah dibeli orang lain.

i. Larangan menimbun barang pada saat masyarakat banyak memerlukan barang tersebut.

j. Larangan jual beli ke arah yang bermaksiat kepada Allah misalnya menjual patung untuk disembah.

k. Larangan jual beli yang mengarah pada unsur paksaan.

1. Dalam jual beli harus terlihat jelas bendanya tetapi, dibolehkan dengan melihat contoh barangnya. ${ }^{20}$

\section{Hukum Jual Beli Dua Harga Dalam Satu Transaksi Jual Beli Perspektif Mazhab Maliki dan Mazhab Syāfi'i}

\section{Pendapat Imam Malik Tentang Jual Beli Dua Harga dalam Satu Transaksi}

Dalam kitab al-Muwatta', ketika menyebutkan atau menuliskan hadis tentang jual beli dua harga dalam satu transaksi jual beli, Imam Malik menjelaskan bahwa bentuk jual beli ini yaitu: pertama, ketika seseorang menjual barang dagangannya kepada orang lain dengan harga sepuluh dinar dengan sistem pembayaran tunai dan lima belas dinar dengan sistem kredit. Kedua, dengan dua harga dari dua barang seperti seseorang yang menjual untanya seharga 20 dinar dengan tunai atau 30 dinar dengan kredit dan menjual dombanya dengan harga 30 dinar dengan tunai atau 40 dinar dengan kredit. Ketiga, yaitu ketika seseorang membeli dari pedagang kurma lima belas sha' atau gandum sepuluh sha' dengan harga dua dinar. Adapun bentuk bentuk pertama dan kedua merupakan jual beli yang dimakruhkan oleh Imam Malik dan bentuk yang ketiga tidak dihalalkan oleh Imam Malik. $^{21}$

Dari pendapat Imam Malik di atas, diketahui bahwa jual beli dua harga dalam satu akad memiliki berbagai macam bentuk. Hal ini mengakibatkan adanya perbedaan hukum meskipun dalam jenis yang sama. Abu al-Hasan Alī bin Sa'̄id, seorang imam fikih bermazhab malikiyyah, dia adalah murid dari al-Qadi ibnu Rusyd dan al-Qadi Iyad, beliau menggambarkan ada tiga bentuk atau kategori dalam jual beli dua harga dalam satu akad, yaitu :

1. Satu barang yang memiliki dua harga

2. Dua barang dengan dua harga yang berbeda

3. Dua barang yang memiliki satu harga

Setelah menjelaskan bentuk-bentuknya, beliau kemudian menjelaskan hukum dari semua bentuk di atas terdiri atas dua hukum, yaitu :

1. Dua barang atau dua harga salah satunya merupakan makanan yang masuk dalam jenis harta ribawiyyah.

\footnotetext{
${ }^{20}$ Sudarsono, Pokok-Pokok Hukum Islam, 1st ed. (Jakarta: Rineka Cipta, 1992).

${ }^{21}$ bin Anas bin Malik bin Amir al Ashbahy al Madaniy, Al Muwaththa'.
} 


\section{Harga atau barang merupakan lahan atau hewan.}

Adapun menurut penjelasan beliau jika salah satu barang atau harga merupakan salah satu dari jenis harta ribawiyyah maka, hukumnya tidak boleh menurut kesepakatan ulama Malikiyyah, hal ini dikarenakan akan munculnya sistem riba pada jual beli ini apakah tafädulan ataupun nasianan. Begitu pula pada semua akad jual beli makanan yang dimana status dari makanan ini belum ada digenggaman pembeli. ${ }^{22}$

Abdullah bin Sāleh al-Fauzan di dalam bukunya Minhatu al-'Allām, ketika mensyarah perkataan atau kalimat dari hadis yang berkaitan dengan jual beli dua harga dalam satu akad, menjelaskan perbedaan pengertian atau gambaran dari ulama tentang jual beli ini, di antaranya:

1. Ketika seseorang menjual baju sepuluh dinar secara tunai dan lima belas dirham secara kredit, ini merupakan penggambaran Imam Malik, Imam Nasāi, dan Sufyan al-Sauri tentang bentuk jual beli dua harga dalam satu akad.

2 Ketika seseorang mengadakan akad yang lain dalam jual belinya, seperti akad salaf, jual beli, penyewaan, atau kerja sama, seperti seseorang yang menjual kendaraannya dengan harga 100 dinar dengan syarat pembeli mau menjual rumahnya kepada penjual dengan harga 200 dinar, atau agar pembeli mau menyewakan rumahnya kepada penjual. Gambaran ini merupan tafsiran dari Hanabilah dan Imam Syafi'i. Kemudian yaitu ketika seseorang menjual barangnya kepada pembeli dengan harga 100 dinar kredit, kemudian penjual tadi membeli lagi barangnya dengan harga di bawah penjualannya. Ini masuk dalam masalah jual beli 'inah, dan ini merupakan gambaran yang diberikan oleh Ibnu Taimiyyah dan ibnu Qayyim atas jual beli ini.

Abdullah bin Sāleh al-Fauzan kemudian menjelaskan bahwa bentuk yang pertama tidak tergolong dalam jual beli dua akad dalam satu akad, melainkan hanya jual beli satu akad dengan harga yang belum jelas. Jika keduanya sepakat sebelum berpisah maka urusan menjadi jelas. Namun, jika berpisah dan tidak ada kejelasan, maka hanya tinggal harga yang tidak diketahui, dan gugurlah salah satu syarat jual beli maka ini tidak dibenarkan, kecuali mereka berpisah hanya untuk mempertimbangkan sistem pembayaran apa yang tepat dikarenakan harga yang berbeda, maka ini jauh dari pada apa yang dimaksudkan oleh hadis. Bentuk kedua sendiri terdapat dua akad di dalamnya, dan ini tidak mengapa, sebagaimana penjelasan Abdurrahman al-Sa'dī bahwa bentuk seperti ini tidak termasuk dalam hadis tersebut. Adapun yang ketiga hukumnya haram, sebagai bentuk sad al-darā' $i$, dari praktek riba agar tidak terjadi.

Dalam kitab Fiqh al-Islām wa Adillatuha, Wahbah Zuhaili mengemukakan pendapat Imam Malik, bahwa jual beli seperti ini dibolehkan dengan dalil bahwa jual beli dua harga dalam satu akad masuk ke dalam bab jual beli khiyār, dimana pembeli akan memilih akad mana yang akan digunkan, dan kemungkinan akan berjalan di antara penjual dan pembeli akad yang disepakati. Seperti halnya seseorang yang mengatakan kepada pembeli "saya menerima akad ini" atau "saya mau membayar dengan sistem ini" dan jika hal ini terjadi, maka syarat dari jual beli telah sempurna. ${ }^{23}$

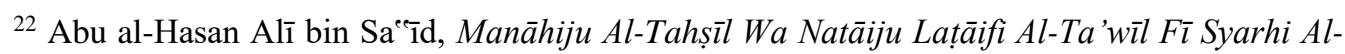
Mudawwanah Wa Hālli Musykilātihā, 1st ed. (Beirut: Dār ibni Hazm, 2007).

${ }^{23}$ Wahbah Zuhaili, Fiqh Al-Islām Wa Adillatuha, IV (Damaskus: Dar al-Fikr, 1985). 


\section{Jual Beli Dua Harga dalam Satu Transaksi Jual Beli Perspektif Imam Syāfi’ $i$}

Imam Syafi'i menggambarkan jual beli dua harga dalam satu transaksi jual beli dalam dua bentuk, yaitu:

1. Ketika penjual menjual kepada pembeli dagangannya dengan harga seribu dirham tunai atau dua ribu dirham cicil, transaksi apapun yang pembeli dan penjual kehendaki maka itulah yang menjadi kesepakatan, maka ini adalah jual beli harga, dan ini perkara yang tidak diketahui.

2. Ketika seseorang menjual budaknya kepada pembeli seribu dinar dengan syarat pembeli menjual rumahnya ke penjual dengan harga yang sama, dan kepemilikan beralih ketika masing-masing sudah selesai dari akadnya, jika terdapat kekurangan dalam jual beli atau penambahan nominal harga maka jual beli ini menjadi rusak.

Adapun bentuk pertama itu menjadi batal dikarenakan terdapat dua harga dalam satu transaksi jual beli secara bersamaan. Begitu juga terdapat jual beli dan persyaratan yang membuat jual beli ini menjadi haram. Ketidak jelasan dari harga dan akad yang disepakati menjadikan jual beli ini batal. Adapun bentuk kedua juga menjadi batal ketika tidak ada kejelasan akad hingga mereka berpisah, meskipun Imam Malik tetap membolehkannya.

Begitupula jika seseorang mengatakan, “Aku menyewakan budakku kepadamu dengan syarat kamu menyewakan rumahmu kepadamu," hukum dari akad penyewaan ini menjadi batal. Seterusnya seperti itu, jika terdapat persyaratan dalam jual beli akad di luar dari jual beli, maka jual beli tersebut batal, apakah dia dua akad dalam satu barang atau dua barang. Adapun jika tidak ada persyaratan yang lain pada dua akad seperti seseorang yang berkata, "Saya menjual budakku ini dengan rumahmu (barter)" maka hukumnya boleh. Akan tetapi, jika seseorang menjual budaknya dengan syarat pembeli menjual rumahnya maka ini tidak sah karena terdapat persyaratan yang mengikat jual beli tersebut. ${ }^{24}$

Wahbah Zuhaili di dalam bukunya juga menjelaskan pendapat Imam Syafi'i memiliki kemiripan dengan pendapat Hanabilah, Imam Syafi'i dan Hanabilah berpendapat bahwa jual beli dua harga dalam satu transaksi jual beli merupakan jual beli yang batal atau tidak boleh, karena ini termasuk dalam jual beli garar atas ketidak jelasan harga. Wahbah Zuhaili menjelaskan bahwa jual beli ini menjadi terlarang dikarenakan penjual terkesan tidak memberikan ketetapan akad yang ditawarkan ke pembeli seperti halnya penjual yang mengatakan, "Saya menjual salah satu rumah saya."25

\section{Komparasi Antara Pandangan Mazhab Maliki dan Mazhab Syafi'i dalam Jual Beli Dua Harga dalam Satu Transaksi Jual Beli}

Di atas telah dipaparkan pendapat Imam Malik dan Imam Syafi'i terhadap jual beli dua harga dalam satu transaksi jual beli. Ada beberapa hal yang dapat diperhatikan dari masing-masing pendapat. Pendapat antara Imam Malik dan Imam Syafi'i memiliki kesamaan, yaitu pelarangan dalam jual beli dua harga dalam satu transaksi jual beli ketika penjual atau pembeli tidak menetapkan satu akad pembayaran hingga mereka berpisah.

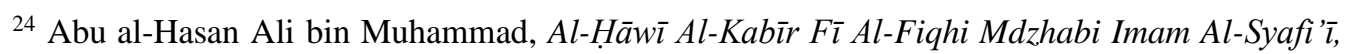
(Beirut: Dar al-Kutub al-Alamiyyah, 1994).

${ }^{25}$ Zuhaili, Al Fiqh Al Islam Wa Adillatuhu.
} 
Hal ini menjadi haram baik dalam pandangan Imam Malik maupun pendapat dari Imam Syafi'i. pelarangan ini didasari oleh garar yang terdapat dalam jual beli tersebut.

Selanjutnya ditemukan perbedaan yang sangat signifikan antara kedua Imam. Imam Malik memandang jual beli seperti ini boleh jika pembeli maupun penjual telah sepakat pada satu akad. Baik itu pembeli yang memilih akad yang digunakan maupun penjual yang menetapkan syarat pada jual beli tersebut. Hal ini juga menjadi boleh, dikarenakan Imam Malik memandang keharaman jual beli ini hanya pada garar yang terdapat pada jual beli tersebut, jika tidak ada kejelasan akad yang ditentukan. Sedangkan menurut Imam Syafi'i dalam memandang jual beli dua harga dalam satu transaksi jual beli hukumnya haram. Hal ini dikarenakan jual beli ini mengandung dua akad di dalamnya. Meskipun akad telah pasti atau telah ditentukan dan disetujui oleh penjual dan pembeli, namun apabila masih terdapat persyaratan yang mengikat jual beli ini maka hukumnya menjadi haram, syarat yang dimaksud adalah perbedaan harga pada tiap opsi pembayaran. Imam Syafi'i memandang bahwa adanya perbedaan harga adalah sebuah "syarat" dalam jual beli ini. Sedangkan jual beli yang terdapat persyaratan yang mengikat di dalamnya maka hukumnya haram.

Jika memperhatikan sabda Rasulullah saw., akan didapati bahwa dalil ini mengacu kepada jual beli dua akad yang tidak ditentukan salah satunya hingga penjual dan pembeli berpisah. Hal ini akan menimbulkan kesalahpahaman antara penjual dan pembeli sehingga menimbulkan kerugian (garar) pada akhirnya. Garar dalam transaksi jual beli merupakan salah satu penyebab yang dapat merusak akad tersebut, pembatalan tersebut bertujuan untuk menghilangkan kerusakan yang akan terjadi jika jual beli ini telah berlangsung. Hal ini sejalan dengan salah satu fungsi atau manfaat diturunkannya hukum islam, yaitu mencegah keburukan dan mengambil manfaat. Adapun pendapat Imam Syafi'i merupakan pendapat yang paling hati-hati dalam masalah ini. karena riba yang dapat muncul maupun terjadi sewaktu akad berlangsung. Ini menunjukkan kehati- hatian Imam Syafi'i dalam mengambil sebuah pendapat atau mengeluarkan sebuah pendapat.

\section{KESIMPULAN}

Menurut Mazhab Maliki, jual beli dua harga dalam satu transaksi jual beli hukumnya boleh selama ada kejelasan akad yang akan digunakan oleh pembeli dan penjual untuk membayar barang yang dijual. Menurut Mazhab Syafi'i, jual beli dua harga dalam satu transaksi hukumnya haram secara mutlak, hal ini dikarenakan adanya ketidakjelasan akad yang dipilih oleh kedua belah pihak. Jika sebuah akad telah ditentukan, hukumnya juga tetap haram karena terdapat persyaratan yang mengikat pada jual beli ini. Persyaratan yang dimaksud ialah, ketika penjual menawarkan dua akad dengan syarat akan ada perbedaan harga antara kedua akad tersebut.

Pandangan Mazhab Maliki condong lebih kuat daripada pandangan Mazhab Syafi'i karena Imam Malik memandang jual beli ini tidak boleh kecuali ada kejelasan akad yang disepakati sebelum berpisah. Penetapan antara dua akad menjadikan jual beli ini boleh menurut Imam Malik. Adapun pendapat Imam Syafi'i justru lebih berhati-hati, karena jual beli seperti ini sangat rentan terjadi kezaliman, praktek riba dan kerusakan yang lainnya. sehingga pada satu waktu pendapat ini juga boleh digunakan. Namun demikian, kedua pendapat ini mengandung kemaslahatan yang besar, yaitu sama-sama tidak membolehkan garar pada transaksinya. Dari pendapat kedua imam besar 


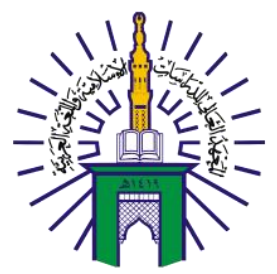

\section{BUSTANUL FUQAHA: \\ JURNAL BIDANG HUKUM ISLAM \\ Vol. 2 No. 2 (2021): Hal. 209-220 \\ EISSN: 2723-6021 \\ Website: https://journal.stiba.ac.id}

tersebut, dapat diambil manfaat bahwa salah satu tugas dari ulama yaitu mencegah dari kerusakan. Selanjutnya, para pakar ekonomi Islam diharapkan dapat memberikan penyuluhan dan pengajaran kepada masyarakat terkait dengan bentuk-bentuk jual beli yang halal dan haram, agar tidak terjadi praktek jual beli yang bertentangan dengan hukum Islam.

\section{DAFTAR PUSTAKA}

Al-Hasan Ali bin Muhammad, Abu. Al-Hāwī Al-Kabīr Fī Al-Fiqhi Mdzhabi Imam AlSyafi ${ }^{\imath}$, . Beirut: Dar al-Kutub al-Alamiyyah, 1994.

Ali bin Hajar al Asqalani, Ahmad bin. Kitab Tahdzib Al Tahdzib. Juz 8. Beirut: Dar alFikr, 1995.

Alī bin Sa'īd, Abu al-Hasan. Manāhiju Al-Tahṣ̄l Wa Natāiju Lațāifi Al-Ta'wīl Fì Syarhi Al-Mudawwanah Wa Hālli Musykilātihā. 1st ed. Beirut: Dār ibni Hazm, 2007.

Ali Hasan, M. Berbagai Macam Transaksi Dalam Islam (Fiqh Muamalat). 1st ed. Jakarta: Raja Grafindo Persada, 2003.

Anas bin Malik bin Amir al Ashbahy al Madaniy, Malik bin. Al Muwaththa'. Beirut: Dar al-Fikr, 1989.

Basyir, Ahmad Azhar. Asas-Asas Hukum Muamalah. Yogyakarta: UII Press, 2009.

Damanuri, Aji. Metodologi Penelitian Mu'amalah. Ponorogo: STAIN Po PRESS, 2010.

Departemen Agama RI. Al Qur'an Dan Terjemahnya. Bandung: Cordoba, 2018.

Din Abu Bakar ibn Muhammad Al-Hussaini, Taqi Al. Kifayah Al Akhyar. 1st ed. Surabaya: Al Haromain, 2005.

Ghazali, Al. Ihya 'Ulum Al Din. Jakarta: Faizan, n.d.

Hadi, Sutrisno. Metode Research. 1st ed. Yogyakarta: Yayasan Penerbit Fakultas Psikologi UGM, 1981.

Hanbal al Syaibani, Abu Abdillah Ahmad bin Muhammad. Al Musnad. Kairo: Dar alHadis, n.d.

- Musnad Al-Imam Ahmad Bin Hanbal. 28th ed. Muassasah ar-Risalah, 2001.

ibn Qasim al Ghazzi, Muhammad. Fath Al-Qarib. Indonesia: Dar al-Ihya al-Kitab, n.d.

Ibnu Abd Azis al Malibary, Zainuddin. Fath Al-Mu'i. Semarang: Toha Putera, n.d.

Isa bin Saurah bin Musa bin adh-Dhohhak at-Tarmidzi, Muhammad. Sunan At-Tarmidzi. Juz 3. Mesir: Syarikah Maktabah wa Matba'ah Mustofa al-Babi al-Halbi, 1975.

Mas'adi, Ghufron A. Fiqh Muamalah Kontekstual. Jakarta: Radjagrafindo Persada, 2002.

Nata, Abuddin. Metode Studi Islam. Jakarta: Raja Grafindo Persada, 2017.

Rahman al Jaziri, Abd Al. Kitab Al-Fiqh 'ala Al-Madzhab Al-Arba'ah. 3rd ed. Bairut: Dar al-Fikr, 1972.

Sudarsono. Pokok-Pokok Hukum Islam. 1st ed. Jakarta: Rineka Cipta, 1992.

Sugiyono. Penelitian Bisnis. Bandung: Alfabeta, 2007.

Suhendi, Hendi. Fiqh Muamalah. Jakarta: Radjagrafindo Persada, 2002.

Syafe'i, Rachmat. Fiqh Muamalah. Bandung: Pustaka Setia, 2001.

Syatibi, Abu Ishaq al. Al Muwafaqat. Beirut Libanon: Dar al-Fikr, 1975.

Yanggo, Huzaemah Tahido. Pengantar Perbandingan Mazhab. Jakarta: Logos, 1997.

Zuhaili, Wahbah. Al Fiqh Al Islam Wa Adillatuhu. 1st ed. Damsiq: Dar al-Fikr, 2006. . Fiqh Al-Islām Wa Adillatuha. IV. Damaskus: Dar al-Fikr, 1985. 